Article

\title{
Does Institutional Context Affect CSR Disclosure? A Study on Eurostoxx 50
}

\author{
Daniela Coluccia, Stefano Fontana * and Silvia Solimene \\ University of Rome, Sapienza, 00185 Roma, Italy; daniela.coluccia@uniroma1.it (D.S.); \\ silvia.solimene@uniroma1.it (S.S.) \\ * Correspondence: stefano.fontana@uniroma1.it; Tel.: +39-0649766455
}

Received: 31 May 2018; Accepted: 20 July 2018; Published: 9 August 2018

\begin{abstract}
We propose to investigate the relationship between corporate social responsibility disclosure and institutional/environmental factors among a sample of European listed companies. We find that, by using several traditional explicative variables, institutional factors affect the level of CSR disclosure, in a context where the EU Commission has been paying growing attention to social and environmental accountability of listed companies (see the EU Dir. 95/2014). Our findings are further supported by multivariate regression, where ESG score (measure of CSR disclosure) is regressed on nine variables which represent the expression of institutional factors. By looking at the institutional determinants of CSR disclosure, we are seeking to pose a challenge for future research agenda, in order to understand whether CSR does actually reflect an effective commitment of firms to accounting practices and rules, as a form of social behavior, or whether it is just a tool to manage stakeholders' perception and to comply with regulation.
\end{abstract}

Keywords: CSR disclosure; institutional context; accounting

\section{Introduction}

Over the last three decades, the research on Corporate Social Responsibility (CSR) reporting has been receiving growing attention by accounting literature. Starting from the definition by Carroll [1], CSR can be seen as a cross linkage between firm and society or collectivity. In such a way, CSR behavior and practices can provide the way companies act to meet the interests of several groups that constitute the society. So, in this way, CSR practices are not to be intended as a tool for legitimating firms' behavior or firms' performance on the market, but it is becoming a very urgent issue to define which groups of stakeholders constitute the whole society and what pressures/expectations CSR practices intend to reply to.

The traditional literature about CSR assumes that CSR practices and behavior are instrumental to financial performance, to reduce reputational risk and to legitimate firms on the market. This literature assumes that instrumental aims may drive the adoption of CSR practices, in an effort to reduce reputational risk and improve financial performance.

The focus of traditional CSR literature is mainly on the characteristics, the content or the extent of CSR disclosure. More recently, literature has been deepening the determinants of CSR disclosure and the theoretical background lying on the back of CSR practices (Gray et al. [2]). Although scholars and practitioners have been wondering about the real motives that induce firms to behave in a sustainable and responsible manner, the greatest part of literature has focused mainly on the links between CSR and financial performance (Anderson and Frankle [3]; Ingram and Frazier [4]; McGuire et al. [5]; Starik and Carroll [6]) as well as the relationship between a firm's internal characteristics (size, profitability) and its external social disclosure (Bhambri and Sonnenfeld [7]; Graves and Waddock [8]). 
But, nowadays, the complex environment in which firms operate, which is defined by legal systems, country risks, norms, and various social groups who have different expectations, produces different pressures all belonging to institutional quality and governance (according to the World Bank Worldwide Governance Indicators [9]). In fact, other motives may be more normative or moral in nature. Here, companies may develop CSR as a response to wider social and institutional pressures (Aguilera et al. [10]). Relying on the perspective of legitimacy theory, it has to be expected that the constraints themselves represent a specific stakeholder, whose expectations firms tend to control by using stakeholder engagement tools. Such a consideration has been forcing a rethinking of the definition and role of CSR practices among firms (Jackson and Apostolakou [11]; Matten, and Moon [12]) at an academic level. In our opinion, firms should perform the stakeholder engagement of such different social groups' expectations, not only to improve financial performance or market appreciation, but also to comply with a more general attitude toward social practices. As for the first aspect, sustainable impact could specifically affect operations' effectiveness, reputation, and in turn, firm market value (Hart [13]; Bajic and Yurtoglu [14]). As for the second aspect, CSR now is a daily activity in firms, voted to realize, affirm and protect corporate and brand reputation. Therefore, in this way, it is possible to conclude that CSR is a general and strategic tool that firms can use to achieve specific economic, social and ecological performance outcomes (Tencati et al. [15]; Wartick and Cochran [16]; Wood [17]).

By looking at the institutional determinants of CSR, we are also seeking to put the challenge for future research agenda, in order to understand if CSR activities actually promote fairness and sustainability in a social way, if the social stakeholder can address corporate behavior and finally what the firm's orientations to profits are. In a few words, we intend to provide an explanation on why firms engage in CSR activities: to contribute effectively to solving the great challenges of our lifetimes, such as climate problems and global inefficiency, or, essentially, just to engage in window dressing?

In our paper, we hypothesize that companies that reach high levels of CSR activity also report it, increasing the CSR disclosure. In this sense, it is possible to assume that the institutional system could affect both social corporates' behavior and disclosure.

For future research, one of the most important aims is to understand whether there could be a significant difference among countries' contextual factors that can affect the effectiveness of CSR disclosure. One would expect that in contexts that are more liberal, firms do adopt CSR practices in a freer manner than in countries where the regulatory system forces the introduction of CSR disclosure as a mandatory practice. However, as we claimed above, the most important achievement for firms should be to behave sustainably and transparently not because they are forced to do this (assuming that CSR is just another way of increasing profits), but because of a very general belief that voluntary sustainable behavior has a market appreciation (Vogel [18]).

The rest of the paper is structured as follows. The theoretical background discusses existing literature on CSR and proxies for environmental factors. Then, the theoretical and empirical literature review on the relation between CSR and institutional factors. Following in Section 5 the research design; the description of the data set and the data source are provided, and the methodology of the empirical research is outlined. Following, the results of the empirical research are analyzed; in the final section, discussion and conclusions are presented.

\section{Theoretical Background}

Despite a great amount of literature puts its efforts in understanding the determinants of CSR, something still remains in the shadows, especially about the reason why firms engage or not in CSR disclosure and practices.

Although there has been a considerable increase in the number of publications on CSR disclosure, only a limited number of them has investigated the relationship between the level of CSR disclosure and the strength of institutional factors.

Investigations on CSR practices and disclosure by firms start from different theoretical backgrounds. 
This topic has been receiving great interest for more than 30 years from scholars from multiple management perspectives, including cost perspective, agency theory, instrumental stakeholder theory, resource-based view (RBV), and reputation theory (Godfrey, Merrill, and Hansen [19]; Muller and Kraussl [20]).

According to Fernando and Lawrence ([21]), the different perspectives belong substantially to "Economic Theories" (such as the agency theory, cost perspective, and positive accounting theory) and "Social Theories" (such as the legitimacy theory, and the stakeholder theory). Even if these theories have different interlinkages, the former look at the economic performance and outcome of CSR practices. The latter pay more attention to the wide plethora of stakeholders and to social outcomes of CSR behavior.

Some scholars have attempted to shed light on the effects produced by institutional factors on CSR disclosure, by using the support of Institutional Theory (IT), among Social Theories, but they reached ambiguous results. In our opinion, the way to understand why firms behave or not in a social manner, passes through the consideration that CSR should be a real and effective commitment by firms towards community and society, and a sincere long term strategy that companies should integrate into policies and procedures. In fact, more recently, institutional theory suggests to reconsider CSR explicitly within different economic fields (Brammer et al. [22]). The interest in CSR has widened to several disciplines, such as politics (Moon [23]; Crouch [24]), economics (van Oosterhout and Heugens [25]), law (Mullerat [26]) and sociology (Brooks [27]). These perspectives take into consideration that CSR is far from being only a strategy of empowering corporate performance, as management literature on CSR stated until now. In this way, IT can be used as a viable route to put CSR at the center of the relationship between business and society. In pursuing the real motivations for CSR practices, IT contributes in various ways. In fact, it allows for a more accurate comprehension at a national level of what CSR in a specific institutional environment actually means. Although the European Union issued a series of Directives in order to pursue a goal of harmonizing the laws of the Member States, at a national level, factors such as economic structure, the role of the nation-state, and the socio-cultural orientation of a country create fundamentally different contexts in which companies interpret their responsibilities towards society and consider actions to fulfil those obligations; so among external factors, the institutional context is very important, and only recently there have been studies that have verified its impact on CSR.

Moreover, IT might provide some insights into normative or coercive implications: the type of institutions that led to the most efficient and stable ways of organizing business activities, why and how firms do engage in social activities, and if there are decoupling mechanisms that force firms to address their behavior in one way (Brammer at al. [22]).

Actually, Institutional Theory brings into the analysis interdependencies between and interactions among stakeholders, which are vital to understanding CSR, given its societal orientation. Institutional theory has established itself as a relevant theory to justify the convergence of companies' behaviors with respect to certain practices as a result of external pressures such as social factors, the presence of norms, environmental policies, history and traditions (Di Maggio and Powell [28]). The acknowledgement that national institutional frameworks for CSR vary across nation-states (Habisch et al. [29]), according to Matten and Moon [12], concludes that there is a substantial difference between the American and the European institutional context, in particular the relationship between the company and society. The explicit approach to CSR, typical in the USA, results from the belief that individual organizations are responsible for societal interests. The implicit approach to CSR, more typical of European firms, reflects organizations' roles within wider institutions that address societal interests. In particular with this term we want to underline that in the European area the companies' commitment is mainly driven by coercive reasons rather than by an instrumental approach (Matten and Moon [12]). Moreover, implicit CSR is not conceived as a voluntary and deliberate corporate decision, but rather as a reflection of a company's institutional environment. In Europe explicit approaches to CSR are a logical outcome in state-society relations. European governments provide greater support for social welfare, education and cultural activities and they act as coordinators of CSR policy and may actively promote CSR. 
In fact, the Civil society has been advocating for many years for a strong mandatory framework for the disclosure of non-financial information by large companies that would improve the quantity and quality of reporting and set a an even playing ground for European business and the result of such pressure has been the introduction of EU Directive 95/2014.

For the abovementioned reasons, in this paper we seek to produce a first attempt to investigate which institutional factors and governance quality and their attributes can affect CSR disclosure on a sample of European companies, over the period 2007-2016. It is well known that firms do adopt their specific procedures and policies to comply and to define their CSR behavior. However, it is also clear how the European Commission, since the 2000s, started to direct firms towards CSR practices. The publication of the Green Paper [30] launched a wide debate on how the EU could promote corporate social responsibility (CSR). Although there is still a lack in the definition of CSR, it is well-known nowadays that CSR consists of the way companies integrate social and environmental concerns in their business operations and in their interaction with their stakeholders, on a voluntary basis. More recently, the EU Commission has been focusing on greater and growing business transparency and accountability on social and environmental issues. The introduction of the aforementioned groundbreaking EU Directive on the disclosure of non-financial and diversity information has set a clear course towards greater business transparency and accountability on social and environmental issues. Consequently, it is likely that the new European directive has been encouraging firms to release increasing CSR disclosure over time. Until now, therefore, literature very rarely has dedicated attention to this topic.

The main contribution of our paper is to establish if there is a relationship between CSR and legal and social/political context variables, also because literature highlighted that CSR behavior is different among countries and institutions. From a stakeholder's perspective, we go further than existing literature, because we consider all environmental and institutional factors as a unique stakeholder, namely the "Institution", as Freeman in 1984 codified, in order to test the role of such a complex and various stakeholder on CSR reporting. In particular, as a measure of CSR reporting produced by firms, we selected one important indicator used in accounting for CSR literature (Eccles and Saltzman [31]): the ESG score ("ESG" is for Environmental, Social and Governance dimension of CSR). So far, indeed, the information on CSR activities has been voluntarily disclosed by firms. After the EU Directive 95/2014, non-financial indicators, such as the CSR ones, have to be disseminated as mandatory disclosure. From an institutional perspective, it means that the globalization of firms' operations increases the homogenization of CSR reporting, by having firms adopting international sustainability guidelines. Although CSR is a voluntary activity, firms reply to societal and governmental pressure to comply with international standards (Einwiller et al. [32]). Such a behavior suggests organizational mechanism among firms, called institutional isomorphism (Moll et al. [33]). In this respect, we try to push the boundaries of stakeholder theory up to those of institutional theory. The latter draws isomorphism and coercive institutionalism, which argue that firms are forced to respond to the pressures exerted by institutionalized stakeholders and that there is a homogenization mechanism when formal and informal expectations and pressures come to firms (Shepard et al. [34]).

\section{Theoretical Literature Review on Institutional Factors and CSR}

According to Ali et al. [35], several studies have attempted to investigate the effect of general contextual factors and CRS disclosure, but findings are not univocal.

Starting from Campbell's conclusions in 2007 [36], responsible behavior is affected by several institutional factors, such as public and private regulations, the presence of institutionalized norms on corporate accounting, cultural systems, and the degree of openness to firm's stakeholders. These forces, coercive and normative, do act systematically on the CSR behavior of firms.

On the one hand, some scholars tested that CSR activity and disclosure are higher in countries with weaker institutions' mechanisms. Jackson and Apostolakou [11] studied the influence of different institutional environments on CSR policies of European firms. They found that firms from Anglo-Saxon countries, considered as more liberal market economies, have a higher level of CSR than companies 
from European economies with a more coordinated market. Corporations operating in countries with stronger institutional factors tend to reach a minimum standard of CSR without achieving the best results. El Ghoul et al. [37] verified that the value implication of CSR is greater in countries with weak institutions and more laissez-faire governments. In other words, by adopting CSR initiatives, companies can fill institutional voids. Jackson and Apostolakou [11] found that CSR acts as a substitute for institutional forces and that it is stronger in liberal market economies.

On the other hand, other research tested a positive relationship between the strong presence of national institutions and CSR initiatives and disclosure. Dhaliwal et al. [38] analyzed the country-level financial opaqueness, the level of legal and public enforcement, the legal environment of a country in protecting labor rights, the presence of a mandatory CSR disclosure, the public awareness of CSR issues and the adoption of IFRS standards. Their results suggest that CSR disclosure is associated with a better informed environment. The association is also stronger among countries with greater opacity in financial disclosure. Ioannou and Serafeim [39] found that the political system, followed by the labor and education system, and the cultural system produce the most important effects on CSR performance. Cahan et al. [40] studied how the strength of national-level institutions affects the level of CSR disclosure. They found that all the variables are positively and significantly related to CSR disclosure. Consequently, the stronger is the level of national institutions, the higher is the level of CSR disclosure. Furthermore, the authors produced an advanced study on the relationship between CSR, market value and institutional factors. Garcia-Sanchez et al. [41] analyzed CSR disclosure of companies in 20 developed countries and investigated the effects produced by the institutional environment. The Authors found that firms located in countries with a strong institutional environment improve the quality of their CSR disclosure. In other words, companies belonging to countries with higher long-term orientation, cultural values of collectivism, feminism and uncertainty avoidance are more sensitive to publishing CSR reports.

The present paper is voted to fill the essential research gap that exists among CSR studies, by testing the relationship between CSR practices and environmental and contingency factors across diverse contexts from a modern institutional theory perspective, whose high aim is to explore the real motivations for CSR practices and disclosure by firms.

For the abovementioned purpose, we start from the abovementioned relevance of the institutional and environmental factors in explaining the level of the adoption of CSR practices and disclosure.

\section{Empirical Literature Review on Institutional Factors and CSR}

CSR can be seen as a voluntary behavior which has a normative effect on the coordination of social units represented by firms. Institutions influence organizations' behavior with norms; in the same way, Institutional Theory can explain CSR activities and disclosure.

In the last ten years, several studies have address the relationship between CSR reporting and environmental factors within institutional theory in order to understand the difference among countries (diversity) and the reason why CSR practices do change and how (Carrol [42]; Blasco and Zolner [43]; Jackson and Apostolakou [11]; Jennings and Hoffman [44]).

Previous studies have already faced the effects of environment and institutions on CSR disclosure on specific countries (Khanna et al. [45]; Xiao et al. [46]; Buhr and Freedman [47]; Thorne et al. [48]). Unfortunately, institutional and environmental factors are not analyzed systematically in these papers, as in our intentions. Another contribution of our paper is that our analysis is performed among countries belonging to the Eurozone, where the code law established high levels of compliance to the rules and regulatory systems. Since Institutional Theory has established that firms belonging to the same context tend to copy and to emulate each other's activities (Di Maggio and Powell [28]), we want to test the effectiveness and the trueness of this statement, by controlling the CSR behavior of firms among the European context, in the same way Shi et al. did to verify the country effect among US companies in CSR practices (Shi et al. [49]). 
However, in recent years, dramatic changes have occurred in the global economy. Across countries, a significant need to go deep into the contingency factors which can affect CSR still remains. Institutional environments, legal systems, the degree of democracy, and the market development should be highlighted as factors that can make the difference among countries in CSR non-financial and voluntary disclosure practices (spending, policies and reporting). In recent studies, some scholars have appealed for more attention to be paid to cross-national comparison (Campbell [36]). However, due to the absence of multinational data, comparative research based on different backgrounds is still rare.

The variables used in the model are taken from the general contextual factors previously codified by empirical literature. The classes we are drawing our variables from are outlined below.

\subsection{Political System}

As for political systems, in 1986 Goodrich [50] claimed that political factors, like political system types and international organizational membership, are significantly linked to accounting practices. Following this concept, later many researchers document that the political conditions are among the most important external factors broadly used in earlier research to explain the differences in corporate disclosures (Adams and Harte [51]; Williams [52]; Adams [53]; Orij [54]). Politics and economics are seen as the science of creating wealth and managing resources (Robbins [55]). Deegan [56] argues that the politics and economics of any country are closely linked and are both considered as ways of organizing organizational behavior and managing potential conflicts; therefore, they cannot be separated from each other (Bani-Khalid and Kouhy [57]). Recently, Frynas and Stephens [58] pushed further the boundaries of CSR, by introducing the term "political CSR", since companies can be actors engaged in changing the institutional environment in which they operate. In the relationship with non-market actors, companies can use traditional political activities such as lobbying, and CSR activities such as strategic philanthropy to reach business objectives.

The political system is an essential component in socio-economic stability for any country, and it is also known as a legitimate power in formulating regulatory decisions that affect society at large (Whitley [59]). Furthermore, a country's political system is defined as a set of laws and customs that regulate the internal and external affairs among individuals and groups within the social structure. The political system is a central factor in the institutional context in which corporations operate, and it influences corporate behavior. On the opposite side, there is a mutual relationship between political context and companies, since the latter are themselves political actors, because they produce services for the community (health, for instance, or education), previously supplied only by the state (Scherer [60]).

Among the various institutional factors studied by literature, political variables are the most important factors that affect corporate disclosure (Ioannou and Serafeim [39]; Williams [52]).

As for practical implication of a political system, it was found that firms with a higher level of democracy tend to disclose more information (Goodrich [50]; De Villiers and Marques [61]). In contrast, Williams ([52]) argued that a low level of corporate disclosure is linked largely with countries that have practiced civil oppression and violations of political rights. In conclusion, as for the linkage between political system and CSR practices and non-financial disclosure, Goodrich ([50]), Williams ([52]), Adams ([53]), anticipated that the political factor can represent quite a good driver of CSR disclosure and practices, which can also reflect either positively or negatively the level of corporate disclosure in a stated country.

The presence of a stable government is a guarantee for companies that operate in a "safe" environment. Moreover, companies perceive a stimulating situation if the activity of the government is effective, or if there is a perception of a high quality of public services and the government's commitment to policy formulation and implementation. The environment in which firms operate has the possibility to evolve and develop, positively acknowledging both the public initiative and the private initiative. In these conditions, companies positively evaluate the possibility of investing 
their resources in socially useful activities, as they perceive that their actions positively affect the environment and consequently produce benefits for them.

Furthermore, listed companies often interact with companies and/or public corporation. In order to be selected as suppliers by public administrations, companies are encouraged to adopt ethical behavior and codes. In this perspective, the perception of operating in an environment free of corruption in which the choices made by the public administrations are based on the quality of the companies stimulates firms to improve their social activities. High corrupted countries with weak political institutions are more likely to fail on the CSR reporting and practices. Corrupted governments manipulate political policies and economic environment to increase profits or decrease costs for a firm or a particular group of companies (Di Tella and Ades [62]). According to the conclusion of De Villier and Marques [61], firms are more likely to disclose CSR information in countries with better investor protection, higher levels of democracy, more effective government services, higher quality regulations, more press freedom, and a lower commitment to environmental policies.

Also political ideologies play a central role in the CSR activities by companies (Walters [63]). Hanlon and Fleming [64] suggested that liberalism and conservatism might also influence corporate social responsibility. It can be argued that societies with liberal values encourage CSR, have a preference for equality, desire for social change, are sensitive towards issues such as inequality, contrary to conservative societies.

\subsection{Legal System}

In the last two decades, also the legal system has been receiving growing interest by accounting literature, in country-level researches (Amor-Esteban et al. [65]; La Porta et al. [66]; Doupnik and Salter [67]). The rule of law can play a central role on accounting practices, especially on voluntary disclosure. Civil law and common law regulatory systems can help account for differences in CSR activities. It can be argued that in a context characterized by stronger legal systems, the implementation of legal accounting provisions may lead firms to pay more attention to finding a deeper level of organizational commitment. Consequently, corporate voluntary reporting could reflect the implementation of such voluntary commitments, in the sense that corporate voluntary disclosure belongs to the existence of a strong and stable legal system. Ball et al. [68], found that civil-law systems are more stakeholder-oriented than common-law systems. On the other hand, CSR disclosure is mainly voluntary, non-mandatory, so that it is hard to understand whether the CSR reporting does reflect effective commitment to accounting practices and rules, in a social behavior manner, or whether it is just a tool to manage stakeholders' perception and to comply with regulation.

On the one hand, in a civil law system, the high obligations regarding mandatory disclosure could encourage companies to provide also high levels of voluntary disclosure. But that is not always true. In some situations, the presence of a strong regulatory system, for instance with a CSR mandatory disclosure, may negatively affect the level of it. Although mandatory CSR forces companies to disseminate information about their economic, social and environmental activities, when CSR disclosure is not a free choice for the companies, it is possible that firms adopt the minimum level requested by law to be in line with the regulatory obligations, without going any further and without reaching the best practices. Therefore, it is not to be taken for granted that the mandatory CSR disclosure automatically produces an improvement of it (Kolk and Perego [69]).

The same results could be obtained analyzing the effects produced by the higher or lower legal protection for investors that characterized civil law countries. The presence of strong investor protection laws could increase the likelihood of adopting minimum standards along the social dimension of CSR. Thus, firms may disclose what is requested by law, just to be in line with the regulatory obligation (Jackson and Apostolakou [11]).

Under an ineffective regulation, firms would act in more irresponsible ways due to the absence of the potential risk of regulatory sanctions. It is the case to remember that, according to Stakeholder Theory, CSR practices and disclosure are a way to improve and legitimate the firms' reputation, finally 
to mitigate agency problems. Some scholars (Williams [52]; Orij [54]) found that firms that operate within legal contexts will have a more responsible attitude towards CSR and sustainability behavior than firms with weaker and more unstable legal systems. Complementary, the lack of accounting regulation in terms of CSR is the reason for the absence of CSR disclosure and of general non-financial disclosure and practices (De Villiers [70]; Momin and Parker [71]).

\subsection{Voice and Accountability}

The World Bank 2010 Governance Indicators stated that this variable represents the extent to which country citizens are able to participate in selecting their government, as well as freedom of expression, freedom of association, and a free media.

This variable is a normative factor which identifies that democratic governments and systems improve the security feeling and self-confident sentiment among citizens about the capacity of laws, of law enforcement agents, and of the judicial system to ensure freedom for all (Simnett, et al. [72]). In this sense, voice and accountability are the reflection of the degree of democracy and freedoms. One can conclude that such a liberal context can ensure and produce as outcome higher non-financial and social disclosures. De Villiers and Marques [61], found that firms are more committed to social disclosures in countries with higher levels of democracy, rather than those which operate in a restricted or unstable context.

\subsection{Cultural System}

Normative pressures in accounting research suggest that culture may play a critical role in determining management behavior in terms of financial allocation of resources and ethical decision-making process with respect to financial and non-financial reporting. This implies cultural values may influence the way firm's resources are allocated and the manner in which that firm shares its financial profitability with stakeholders (Garcia-Sanchez et al. [41]). Cultural dimensions are defined as: individualism/collectivism, gender in society, tolerance of uncertainty, the level of hierarchy in society, long-term orientation (Hamamura [73]; Hofstede [74]).

Furthermore, as regards the labor market, companies' activity could be affected also by the power of trade unions. In countries with stronger labor unions, which push companies to improve their social activity, especially with regard to employees' benefits, firms may adopt more social measures to satisfy the labor unions' requests (Ioannou and Serafeim [39]).

Another factor analyzed by the literature concerns the cultural public pressure for CSR disclosure. In this sense, it is possible to distinguish between countries with cultural systems oriented or not oriented to CSR. According to legitimacy theory, companies respond to public pressure to disseminate information about their activity. Thus, we can argue that companies in countries with a higher public pressure for CSR, with a cultural system oriented to CSR, disclose more voluntary information on their economic, social and environmental disclosure (Garcia-Sanchez et al. [41]; Kolk and Perego [69]).

Recently a growing body of literature has been paying attention to many other cultural variables that can affect voluntary disclosure and practices. Among these, there are studies on board diversity (Barako and Brown [75]; Ntim [76]; Ntim and Soobaroyen [77]) and ownership structure (Al-Bassam et al. [78]; Tagesson et al. [79]).

\subsection{Economic System}

As regards the economic context, it is possible to consider different factors. Among these factors, a critical one is the level of market competition and development (Doh and Guay [80]). To our opinion a highly competitive environment for firms increases the likelihood to engage in a socially irresponsible manner through increasing profits and decreasing costs and risks. Following Macaulay's conclusions [81], when competition is weak (e.g., monopoly or a situation where firm value is not at risk and profits are modest) companies will have fewer incentives to engage in socially irresponsible activities, as opposed to Williamson ([82]). 
Some scholars have focused their attention on the development of economic environment, studying the differences in corporate reporting among developed and developing countries. They conclude that developed countries reach a higher level of disclosure, both mandatory and voluntary (Gray [83]). At an empirical level, several studies have investigated the relationship between corporate disclosure and the efficiency and development of the equity market, measured by the size and the activity of the financial market (Adhikari and Tondkar [84]; Doupnik and Salter [67]; Gray et al. [85]). These scholars argued that as the size and the activity of equity market increase, buyers and sellers exert pressures on companies to give more voluntary disclosure to reduce potential information asymmetries.

Another economic factor analyzed by literature is the country's market structure. Probably in countries with a high number of big and international companies, the pressure to disseminate CSR disclosure, as well as mandatory disclosure, is stronger than in countries with small or medium enterprises. The big corporations generally operate in different countries and must satisfy different regulatory systems; they could face different and even conflicting requirements in different countries (Marano and Kostova [86]). Multinational companies are more likely to adopt a higher standard of disclosure in order to be compliant to all different regulator's systems.

\section{Research Design}

As we said, in our paper we want to test if the institutional characteristics of a country could produce effects on a company's behavior and on a company's social disclosure. In other words, we want to verify whether and how the CSR disclosure has been affected by the stakeholder's "institutions". To do that, we performed a multivariate analysis, using the CSR disclosure as dependent variable, and the measure of the quality of national institutions as explicative variables. In the model we also included a set of control variables identified in the prior literature as related to companies' CSR level.

\subsection{Sample Selection}

We have collected social and financial variables over five years: from 2007 to 2016 . We collected this information for a homogenous sample composed of companies belonging to Eurostoxx 50 index, introduced in February 1998 by Stoxx Limited, with the aim of representing the fifty largest capitalization stocks and Eurozone countries. We selected the companies belonging to the index at 31 December 2016 and for each one we collected all the data we used to perform the regressions. The selection of the sample consisted in the exclusion of companies with at least one set of data not present in any year over the period 2007-2016.

The companies of our sample operate in the following European countries (Table 1).

Table 1. Sample Selection.

\begin{tabular}{ccc}
\hline Country & Eurostoxx 50 & Our Sample \\
\hline France & 20 & 16 \\
Germany & 14 & 13 \\
Spain & 5 & 1 \\
Netherlands & 5 & 3 \\
Italy & 3 & 2 \\
Belgium & 1 & 1 \\
Ireland & 1 & 0 \\
Finland & 1 & 1 \\
Total & 50 & 37 \\
\hline
\end{tabular}

\subsection{Dependent Variable}

To measure CSR disclosure, we selected the ESG score. The ESG score represents the judgement about environmental, social and governance disclosure of the company. We collected this indicator from Bloomberg database which covers 120 environmental, social and governance indicators including a big 
variety of items. Bloomberg evaluates companies on an annual basis, collecting public ESG information disclosed by companies through corporate social responsibility (CSR) or sustainability reports, annual reports and websites, and other public sources, as well as through company direct contact.

\subsection{Explicative Variables}

As regards the explicative variables, among the different institutional factors studied by literature, we focused our attention on the following:

- Voice and Accountability: perceptions of the extent to which a country's citizens are able to participate in selecting their government, as well as freedom of expression, freedom of association, and a free media. According to De Villiers and Marques [61]:

Hypothesis 1 (H1). There is a positive relationship between Voice and Accountability and CSR disclosure.

- Political Stability and Absence of Violence/Terrorism: perceptions of the likelihood that the government will be destabilized or overthrown by unconstitutional or violent means, including politically-motivated violence and terrorism. To our study, this variable belongs to Political System factors. According to Hanlon and Fleming [64]:

Hypothesis 2 (H2). There is a positive relationship between Political Stability and Absence of Violence/ Terrorism and CSR disclosure.

- Government Effectiveness: perceptions of the quality of public services, the quality of the civil service and the degree of its independence from political pressures, the quality of policy formulation and implementation, and the credibility of the government's commitment to such policies. To our study, this variable belongs to Political System factors. According to De Villiers and Marques [61] and to Goodrich [50]:

Hypothesis 3 (H3). There is a positive relationship between Government Effectiveness and CSR disclosure.

The following variables belong, to our opinion, to Legal System factors. The sign of the relationship is in line with Ball et al. [68].

- Regulatory Quality: perceptions of the ability of the government to formulate and implement sound policies and regulations that permit and promote private sector development. According to Ball at al. [68]:

Hypothesis 4 (H4). There is a positive relationship between Regulatory Quality and CSR disclosure.

- Rule of Law: perceptions of the extent to which agents have confidence in and abide by the rules of society, and in particular the quality of contract enforcement, property rights, the police and the courts, as well as the likelihood of crime and violence;

Hypothesis 5 (H5). There is a positive relationship between Rule of Law and CSR disclosure.

- Control of Corruption: perceptions of the extent to which public power is exercised for private gain, including both petty and grand forms of corruption, as well as "capture" of the state by elites and private interests. To our study, this variable belongs to Political System factors. According to De Villiers and Marques [61]:

Hypothesis 6 (H6). There is a negative relationship between Control of Corruption and CSR disclosure.

We selected the above explicative variables from the World Bank Development Research Group among the Worldwide Governance Indicators (WGI) project. We chose these indicators because the 
data allow us to analyze over 200 countries and are constantly updated, measuring six dimensions of national governance quality starting in 1996. They are also widespread in literature (Cahan et al. [40]). These indicators are based on several hundred variables obtained from 31 different data sources, capturing governance perceptions as reported by survey respondents, nongovernmental organizations, commercial business information providers, and public sector organizations worldwide.

Moreover, in addition to the ones above, in our model we add one further variable, which according to our opinion, can better shape the relationship between CSR and institutional factors: "Number of domestic listed companies". This variable represents domestic market development; it is deduced from the IMD World Competitiveness Yearbook (WCY), first published in 1989, which is a comprehensive annual report and worldwide reference point on the competitiveness of countries. It provides benchmarking and trends, as well as statistics and survey data based on extensive research. It analyzes and ranks countries according to how they manage their competencies to achieve long-term value creation.

Hypothesis 7 (H7). There is a positive relationship between Number of domestic listed companies and CSR disclosure.

\subsection{Control Variables}

In the model, we also included a set of control variables identified in the prior literature as related to companies' CSR disclosure.

\subsubsection{Financial Situation}

In general, it can be assumed that, especially during periods of economic and financial crisis, it is very likely that companies with a high level of financial debt disseminate more voluntary information in order to 'settle' all stakeholders.

With reference to the financial situation, we selected the leverage and measured the ratio between the total financial debt and equity (Cormier et al. [87]; Déjean and Martinez [88]; Malone et al. [89].

In order to better define the financial situation of firms, we also added the Probability of Default, which is a variable literature has already considered in the CSR accounting researches (Najah et al. [90]; Cheng et al. [91]) and which, in our opinion, can explain the effective appreciation by analysts of the access to financial market by companies.

Such an indicator is important not only for debt holders, but also for the wide variety of stakeholders. For financial investors, default risk does affect stock returns, in the sense that high risk default is linked to low stock returns. The credit risk rating of a firm, especially the long-term one, can improve the chances to start long-term operational investment activities, such as those related to CSR. Default risk is the capability of a firm to pay its obligations by its future cash flows. It affects a firm's cash flow vulnerability (Cornell and Shapiro [92]). We selected from Bloomberg database the 5 years default probability, to consider a time horizon of medium duration within which the analyzed variables can produce effects on the firm value. Bloomberg's default risk dataset provides an independent evaluation of a company's credit health, using market data (share price and volatility), fundamental data, and cutting-edge quantitative models. The probability of default of the company over the following 5 years is calculated by the Bloomberg Issuer Default Risk Model.

Hypothesis 8 (H8). There is a relationship between financial situation and CSR disclosure.

\subsubsection{Firm Size}

Among the variables that positively affect disclosure, international literature has generally included firm size (Adams et al. [93]; D’Amico et al. [94]; García-Sánchez [95]). There are various reasons for this inclusion. Firstly, large companies can produce additional information that is required by the mandatory accounting procedures at lower costs than small- and medium-sized enterprises. 
In addition, large companies which aspire to improve their 'social appreciation' should meet the expectations of a wide range of stakeholders and, therefore, should produce more information.

Regarding the size of the company, we used the logarithm of total assets to reduce the variability and keep in line with the main studies on the subject (Stanny and Ely [96]).

Hypothesis 9 (H9). There is a positive relationship between Size and CSR disclosure.

\subsubsection{Age}

In general, it can be said that a company that has been on the market for longer has a better and more consolidated control and reporting structure and can devote more time to refining other information systems. In this sense, it can also be assumed that a company can supplement the ordinary and voluntary information with further disclosure related to social responsibility. For these reasons, greater voluntary disclosure should be observed for firms with longer histories on the market. On the other hand, there is no doubt that the public directs more attention to a company's CSR when the company enters the capital market. Listed companies, in fact, are those which have a higher profile than other firms and are constantly brought to the attention of the media, investors etc. (Cormier et al. [87]; Guthrie and Parker [97]; Stanny and Ely [96]; Tagesson et al. [79]).

In our model, the age of a firm is measure by company's birth date.

Hypothesis 10 (H10). There is a positive relationship between Age and CSR disclosure.

\section{Results}

\subsection{Selected Sample}

The firms in sample have been selected from among companies listed on the Eurostoxx 50 index. As we said above, the sample consists of 37 public listed companies. In the following table (Table 2) all selected companies are presented.

Table 2. Selected companies.

\begin{tabular}{cccc}
\hline Firm & Country & Firm & Country \\
\hline Adidas & Germany & Lvmh & France \\
Air Liquid & France & L'oreal & France \\
Airbus Group & France & Nokia & Finland \\
Anheuser Busch & Belgium & Orange & France \\
Asml & Netherlands & Philips & Netherlands \\
Basf & Germany & Safran & France \\
Bayer & Germany & Saint-Gobain & France \\
Bmw & Germany & Sanofi Aventis & France \\
Daimler & Germany & Sap & Germany \\
Danone & France & Schneider Elect. & Germany \\
Deutsche Bank & Germany & Siemens & Germany \\
Deutsche Post & Germany & Telefonica & Spain \\
Deutsche Telekom & Germany & Total & France \\
E on se & Germany & Unibail Radamco & France \\
Enel & Italy & Unilever & Netherlands \\
Engie & France & Vinci & France \\
Eni & Italy & Vivendi & France \\
Essilor & France & Volkswagen & Germany \\
Fresenius Se & France & & \\
\hline
\end{tabular}

\subsection{Descriptive Statisitics}

This paragraph will present the data analysis and results. The descriptive statistics for all variables in the study will be presented in the next section, followed by some diagnostic tests, and finally, 
the regression model for the determinants of the CSR disclosure. The table presents the summary of descriptive statistics for all variables. This table (Table 3) reports the mean, median, standard deviation, maximum, minimum, skewness, kurtosis and the number of observations for each of the variables.

Table 3. Descriptive Statistics.

\begin{tabular}{|c|c|c|c|c|c|c|c|c|c|}
\hline Variable & Symbol & Mean & Median & Max & Min & Std. Dev. & Skewness & Kurtosis & Obs. \\
\hline CSR Disclosure & ESG & 50.515 & 51.240 & 72.314 & 12.810 & 10.441 & -0.814 & 4.348 & 370 \\
\hline Voice and Accountability & VA & 1.288 & 1.298 & 1.606 & 0.912 & 0.137 & -0.199 & 3.131 & 370 \\
\hline Political Stability & PS & 0.984 & 0.996 & 1.488 & -0.474 & 0.296 & -1.559 & 7.040 & 370 \\
\hline Regulatory Quality & $\mathrm{RQ}$ & 1.377 & 1.312 & 1.976 & 0.642 & 0.288 & -0.093 & 2.255 & 370 \\
\hline Rule of Law & $\hat{R L}$ & 1.520 & 1.520 & 2.100 & 0.265 & 0.325 & -2.076 & 8.389 & 370 \\
\hline Control of Corruption & $\mathrm{CC}$ & 1.540 & 1.532 & 2.401 & -0.030 & 0.437 & -1.662 & 6.871 & 370 \\
\hline Probability of Default in Five Years & PD & 0.013 & 0.010 & 0.120 & 0.001 & 0.011 & 3.432 & 27.098 & 370 \\
\hline Size & LNA & 11.011 & 10.938 & 14.605 & 8.164 & 1.081 & 0.374 & 4.407 & 370 \\
\hline Firm's Age & Age & 76.014 & 63.000 & 273.000 & 1.000 & 60.209 & 0.962 & 3.834 & 370 \\
\hline
\end{tabular}

The mean and median in the table above were computed to find the central tendency of each variable for the 37 firms in the sample. The standard deviation indicates the sample's dispersion level of the variables. According to the above table, the companies CSR disclosure over the period 2007-2016 reaches an average a sufficient score of 50.5 which means that the CSR disclosure is quite good (remember that the maximum number in the ESG is 100).

\subsection{The Model}

A time series and cross-section panel data was constructed. The regression can, therefore, be summarized in the following multivariate model:

$$
E S G=\alpha+\beta_{1} V A+\beta_{2} P S+\beta_{3} G E+\beta_{4} R Q+\beta_{5} R L+\beta_{6} C C+\beta_{7} N L+\beta_{8} L e v+\beta_{9} P D+\beta_{10} L N A+\beta_{11} \text { Age }
$$

\subsection{Multiple Regression}

Before making the regressions, we verified the multicollinearity among the explicative variables through the use of VIF (variance inflation factor). According to the results, there is no multicollinearity among the variables since the inter-correlations among the explanatory variables are low.

The present study used panel data analysis technique because the panel data allows for the control of individual heterogeneity. This heterogeneity cannot be controlled by time series and cross section analysis; hence, the results could be biased. Both the fixed effects model and the random effects model can be run in a panel data analysis. To determine which of these regressions should be used in this study, two tests can be performed, as explained below. The analysis can be performed in fixed effects or random effects model. To choose between these two regressions models, the Hausman test can be run to examine whether the difference between the random effects regression and the fixed effects regression is zero. In other words, H0: random effect is preferred. Based on the present analysis, $\mathrm{H} 0$ was strongly rejected $(p$-value $=0.000)$ which means that the fixed effects model was preferred.

We estimated multiple regression to analyze the effect of "Institutional context" on firm's CSR disclosure. Table 4 reports the regression results of the equation and VIF's values.

According to the results reported in the table, it is concluded that the regression model fits the data and the whole model is statistically significant $\left(R^{2}=0.81, p\right.$-value $\left.=0.00\right)$. As shown in the above table, adjusted $R^{2}$ is 0.78 which means about $78 \%$ of CSR disclosure is explained by independent variables in the model. In other words, in Eurostoxx public listed companies, the CSR disclosure is affected by independent variables present in the model. Looking at the analysis, it is appropriate to focus on the single variables that led to statistically significant results compared to what is asserted by theories and empirical verifications. 
Table 4. Multivariate regression analysis results.

\begin{tabular}{|c|c|c|c|c|c|}
\hline Variable & Coefficient & Std. Error & $t$-Statistic & Prob. & VIF \\
\hline $\mathrm{CC}$ & -3.699 & 4.460 & -0.829 & $0.008^{* * *}$ & 1.850 \\
\hline Age & 0.525 & 0.092 & 5.716 & $0.000^{* * *}$ & 1.607 \\
\hline GE & -1.537 & 5.055 & -0.304 & 0.761 & 2.355 \\
\hline Lev & 0.056 & 0.107 & 0.519 & 0.604 & 1.222 \\
\hline LNA & 0.199 & 1.173 & 0.170 & $0.065^{* *}$ & 1.490 \\
\hline NL & -0.004 & 0.003 & -1.219 & 0.224 & 1.857 \\
\hline PD & -24.985 & 31.358 & -0.797 & $0.046^{* *}$ & 1.146 \\
\hline PS & -6.268 & 3.358 & -1.867 & 0.663 & 1.650 \\
\hline $\mathrm{RQ}$ & 13.029 & 4.368 & 2.983 & $0.003^{* * *}$ & 2.545 \\
\hline $\mathrm{RL}$ & 0.296 & 5.418 & 0.055 & $0.057^{* *}$ & 1.786 \\
\hline VA & 12.534 & 6.802 & 1.843 & $0.066^{* *}$ & 1.880 \\
\hline Constant & 23.829 & 16.975 & 1.404 & 0.161 & \\
\hline R-squared & 0.811 & & & & \\
\hline Adj. R-squared & 0.781 & & & & \\
\hline F-statistic & 27.119 & & & & \\
\hline Prob (F-statistic) & 0.000 & & & & \\
\hline
\end{tabular}

\section{Discussion}

Table 5 summarizes and compares the results/signs obtained with those predicted.

Table 5. Results: predicted and obtained signs. NS = no statistical significance.

\begin{tabular}{ccccc}
\hline Variable & Symbol & Hypothesis & Predicted Sign & Regression Result \\
\hline Voice and Accountability & $\mathrm{VA}$ & $\mathrm{H}_{1}$ & + & + \\
Political stability & $\mathrm{PS}$ & $\mathrm{H}_{2}$ & + & $\mathrm{NS}$ \\
Government Effectiveness & $\mathrm{GE}$ & $\mathrm{H}_{3}$ & + & $\mathrm{NS}$ \\
Regulatory Quality & $\mathrm{RQ}$ & $\mathrm{H}_{4}$ & + & + \\
Rule of Law & $\mathrm{RL}$ & $\mathrm{H}_{5}$ & + & + \\
Control of Corruption & $\mathrm{CC}$ & $\mathrm{H}_{6}$ & - & - \\
N. of listed domestic companies & $\mathrm{NL}$ & $\mathrm{H}_{7}$ & + & $\mathrm{NS}$ \\
Leverage & $\mathrm{Lev}$ & $\mathrm{H}_{8}$ & $+/-$ & - \\
Probability of default on 5 years & $\mathrm{PD}$ & $\mathrm{H}_{9}$ & $+/-$ & + \\
Size & $\mathrm{LNA}$ & $\mathrm{H}_{10}$ & + & + \\
Firm's age & $\mathrm{Age}$ & $\mathrm{H}_{11}$ & + & + \\
\hline
\end{tabular}

Regarding the control variables, the regression highlights a positive and significant relationship between CSR disclosure and size. This would seem to confirm the hypothesis 10 that larger companies can afford to make even greater non-mandatory disclosures because of the relatively low cost of such disclosures relative to overall business costs (Adams et al. [93]; García-Sánchez [95]; Stanny and Ely [96]). This hypothesis is consistent with the theory of legitimacy, which indicates that larger companies are more inclined to disseminate information to satisfy a wide range of stakeholders who require information (Bansal and Clelland [98]). With reference to age $\left(\mathrm{H}_{11}\right)$, which represents the birth date of the firm, the regression returns a positive highly significant coefficient, it can be said that a company that has been on the market for longer has better consolidated its control and reporting structure, making it able to devote more time to refining other information systems. In this sense, it can also be assumed that the company can supplement the ordinary and voluntary information. Our results confirm greater disclosure should be observed for firms with longer histories on the market. With reference to companies' financial situation we have chosen two variables: leverage $\left(\mathrm{H}_{8}\right)$ and the probability of default over five years $\left(\mathrm{H}_{9}\right)$. The first one is not significant but the second one, the probability of default, estimated over a medium-term period of five years, has a strong and 
negative statistical significance. CSR disclosure also helps firms build customer loyalty, gain employee support and reduce information asymmetry among all firms' stakeholders. This undoubtedly reduces a company's risk of facing financial penalties and lawsuits. In practice, companies with better social ratings are expected to have less financial risk than companies with poor social ratings (Benlemlih and Girerd-Potin [99]; Chang et al. [100]).

Regarding the variables chosen as measure of the Institutional context (social, political and legal), according to our hypothesis, Voice and Accountability $\left(\mathrm{H}_{1}\right)$, is positive and statistically significant at the $5 \%$ level. As we said, this variable identifies that democratic governments and systems improve the security feeling and self-confident sentiment among citizens about the capacity of laws, of law enforcement agents, and of the judicial system to ensure freedom for all (Simnett, et al. [72]). In this sense, voice and accountability are the reflection of the degree of democracy and freedoms. One can conclude that such a liberal context can ensure and produce higher non-financial and social disclosures as outcomes (De Villiers and Marques [61]). Since companies today fill the social void by offering other services, and since they increasingly play public roles, a democracy ideal would require that these organizations are subject to some form of regulation to "blend" their financial goals with their social and political commitment goals-CSR (Hussain and Moriarty [101]).

Regulatory Quality $\left(\mathrm{H}_{4}\right)$ and Rule of Law $\left(\mathrm{H}_{5}\right)$ are both positive and statistically significant, respectively at the $1 \%$ and $5 \%$ level, according to previous studies (Ball et al. [68]). If the activity of the government is effective, if the government issues laws aimed at improving a country's political system, there is a perception of a high quality of public services and of the government's commitment to policy formulation and implementation. In these conditions, companies perceive a stimulating situation and positively evaluate the possibility of investing their resources in socially useful activities, as they perceive that their actions positively affect the environment and consequently produce benefits for themselves.

Control of Corruption $\left(\mathrm{H}_{7}\right)$ is negative and statistically significant at the $1 \%$ level. In other words, the higher the level of a Country's Corruption, the lower is the quality of CSR disclosure of large European listed Companies. Our results confirm previous studies (Ioannou and Serafeim [39], Baldini, et al. [102]). Considering the effects of corruption, it can be said that stakeholders place a high value on socially responsible and transparent behavior, but in countries characterized by high levels of corruption, companies tends to have lower levels of CSR disclosure. This effect is related to the social and environmental dimensions of CSR, rather than the economic dimension of CSR, which captures overall transparency and measures (Jackson and Apostolakou [11]).

The results show that where there is a strong legal system, there is also a good level of CSR disclosure. Where social norms are strongly expressed, for example, through the media, firms have been shown to react with additional CSR disclosure (De Villiers and Marques [61]), but as Jackson and Apostolakou [11] point out firms adopting 'minimum standards' of CSR could be an asymmetric effect; however this regulatory system has little influence on the firm's adoption of best practices.

Some scholars as Doidge et al. [103] argue that financial globalization decreases the importance of the home-country legal protection. In this context, there has been a spirited debate as to whether and how a firm's home-country legal institutions still play a role in determining firm-level CSR disclosure once the firm has its own access to the global capital market.

Our fist main conclusion is that social, political and legal dimensions exert important pressure on firms improving the transparency of corporate behavior in particular on CSR disclosure.

Our analysis of institutional context supports the evidence that three institutional variables, as we expected, positively affect the level of CSR disclosure, such as regulatory quality, rule of law and voice and accountability.

Contrary to our hypothesis political stability (PS), governance effectiveness (GE) and number of listed companies (NL) resulted non-significant. Consequently, the hypotheses $\mathrm{H}_{2}, \mathrm{H}_{3}$ and $\mathrm{H}_{7}$ are not supported. 
As we said, so far, the information on CSR activities has been voluntarily disclosed by firms. After the EU Directive 95/2014, starting in year 2017, non-financial indicators, such as the CSR ones, have to be disseminated as mandatory disclosure. The introduction of the groundbreaking EU Directive on the disclosure of non-financial and diversity information (Directive 2014/95/EU) has set a clear course towards greater business transparency and accountability on social and environmental issues.

We are convicted that, as for the sample size, the paper suffers from a limitation. We need to specify that, although the sample is small, it represents the most important firms in Europe and consequently the best practices on CSR disclosure. Thus, the present research is the first step of a wider project to enlarge the analysis among a bigger sample.

As future development of the research, it would be interesting to perform the analysis after the introduction of the directive and compare the results, in order to understand if firms have a sustainable and transparent behavior because they are forced to do this (if CSR is just another way of increasing profits), or because of a very general belief that voluntary sustainable behavior has a market appreciation (Vogel, 2006).

Finally, at a managerial level, the comprehension of institutional factors which affect CSR disclosure can also help to understand the effects of the same institutional factors on organizational and internal variables, such as the corporate governance structure, in order to suggest to management which is the best business model to respond to pressures coming from social and institutional environment.

Author Contributions: As regards the contribution of the authors to the work, they declare that the content is attributable to the joint work, therefore indivisible, of all three authors.

Funding: This research received no external funding.

Conflicts of Interest: The authors declare no conflict of interest.

\section{References}

1. Carroll, A.B. A Three-Dimensional Conceptual Model of Corporate Performance. Acad. Manag. Rev. 1979, 4, 497-505. [CrossRef]

2. Gray, R.; Owen, D.; Adams, C. Some theories for social accounting? A review essay and a tentative pedagogic categorisation of theorisations around social accounting. In Martin Freedman; Sustainability, Environmental Performance and Disclosures (Advances in Environmental Accounting and Management, Volume 4); Jaggi, B., Ed.; Emerald Group Publishing Limited: Bingley, UK, 2009; pp. 1-54.

3. Anderson, J.E.; Frankle, A.W. Voluntary Social Reporting: An Iso-Beta Portfolio Analysis. Account. Rev. 1980, 55, 467-479.

4. Ingram, R.W.; Frazier, K.B. Narrative disclosures in annual reports. J. Bus. Res. 1983, 11, 49-60. [CrossRef]

5. McGuire, J.; Sundgren, A.; Schneeweis, T. Corporate social responsibility and financial performance. Acad. Manag. J. 1988, 31, 854-872.

6. Starik, M.; Carroll, A.B. In Search of Beneficence. Proc. Int. Assoc. Bus. Soc. 1990, 1, 1-15. [CrossRef]

7. Bhambri, A.; Sonnenfeld, J. Organization Structure and Corporate Social Performance: A Field Study in Two Contrasting Industries. Acad. Manag. J. 1988, 31, 642-662.

8. Graves, S.B.; Waddock, S.A. Institutional Owners and Corporate Social Performance. Acad. Manag. J. 1994, 37, 1034-1046. [CrossRef]

9. The Worldwide Governance Indicators (WGI). Available online: http:/ /info.worldbank.org/governance/ wgi/index.aspx\#home (accessed on 6 August 2018).

10. Aguilera, R.V.; Rupp, D.E.; Williams, C.A.; Ganapathi, J. Putting the S Back in Corporate Social Responsibility: A Multilevel Theory of Social Change in Organizations. Acad. Manag. Rev. 2007, 32, 836-863. [CrossRef]

11. Jackson, G.; Apostolakou, A. Corporate Social Responsibility in Western Europe: An Institutional Mirror or Substitute? J. Bus. Ethics 2010, 94, 371-394. [CrossRef]

12. Matten, D.A.; Moon, J. Implicit and Explicit CSR, a Conceptual Framework for Understanding of Corporate Social Responsibility. Acad. Manag. Rev. 2008, 33, 404-424. [CrossRef]

13. Hart, S. A natural resource-based view of the firm. Acad. Manag. Rev. 1995, 20, 986-1014. [CrossRef]

14. Bajic, S.; Yurtoglu, B. Which aspects of CSR predict firm market value? J. Cap. Mark. Stud. 2018. [CrossRef] 
15. Antonio, T.; Perrini, F.; Pogutz, S. New Tools to Foster Corporate Socially Responsible Behavior. J. Bus. Ethics 2004, 53, 173-190. [CrossRef]

16. Wartick, S.L.; Cochran, P.L. The Evolution of the Corporate Social Performance Model. Acad. Manag. Rev. 1985, 10, 758-769. [CrossRef]

17. Wood, D.J. Corporate Social Performance Revisited. Acad. Manag. Rev. 1991, 16, 691-718. [CrossRef]

18. Vogel, D. The Market for Virtue. The Potential and the Limits of Corporate Social Responsibility by; Brookings Institute Press: Washington, DC, USA, 2005; ISBN 0-8157-9076-7.

19. Godfrey, P.C.; Merrill, C.B.; Hansen, J.M. Institutional stakeholders and the insurance value of CSR. The relationship between corporate social responsibility and shareholder value: An empirical test of the risk management hypothesis. Strateg. Manag. J. 2009, 30, 425-445. [CrossRef]

20. Muller, A.; Kraussl, R. Doing good deeds in times of need: A strategic perspective on corporate disaster donations. Strateg. Manag. J. 2011, 32, 911-929. [CrossRef]

21. Fernando, S.; Lawrence, S. A Theoretical Framework for CSR Practices: Integrating Legitimacy Theory, Stakeholder Theory and Institutional Theory. J. Theor. Account. Res. 2014, 10, 149-178.

22. Brammer, S.; Jackson, G.; Matten, D. Corporate Social Responsibility and institutional theory: New perspectives on private governance. Socio-Econ. Rev. 2012, 10, 3-28. [CrossRef]

23. Moon, J. The Social Responsibility of Business and New Governance. Gov. Oppos. 2002, 37, $385-408$. [CrossRef]

24. Crouch, C. Privatized Keynesianism: An Unacknowledged Policy Regime. Br. J. Politics Int. Relat. 2009, 11, 382-399. [CrossRef]

25. Oosterhout, J.H.V.; Heugens, P.M.A.R. Much Ado about Nothing: A Conceptual Critique of CSR. In The Oxford Handbook of Corporate Social Responsibility; Crane, A., McWilliams, A., Matten, D., Moon, J., Siegel, D., Eds.; Oxford University Press: Oxford, UK, 2008; pp. 197-223.

26. Mullerat, R. (Ed.) Corporate Social Responsibility: The Corporate Governance of the 21st Century; Kluwer Law International: Boston, MA, USA, 2005.

27. Brooks, S.B. CSR and the Strait-jacket of Economic Rationality. Int. J. Sociol. Soc. Policy 2010, 30, 604-617. [CrossRef]

28. DiMaggio, P.J.; Powell, W. The iron cage revisited institutional isomorphism and collective rationality in organizational fields. Am. Sociol. Rev. 1983, 48, 147-160. [CrossRef]

29. Habisch, A.; Jonker, J.; Wegner, M.; Schmidpeter, R. Corporate Social Responsibility across Europe; Springer: Berlin, Germany, 2005.

30. European Commission. Green Paper. Promoting a European Framework for Corporate Social Responsibility, Brussels, 18 July 2001. Available online: europa.eu/rapid/press-release_DOC-01-9_en.pdf (accessed on 6 August 2018).

31. Eccles, R.G.; Saltzman, D. Achieving sustainability through integrated reporting. Stanf. Soc. Innov. Rev. 2011, $59,56-61$.

32. Einwiller, S.; Ruppel, C.; Schnauber, A. Harmonization and differences in CSR reporting of US and German companies: Analyzing the role of global reporting standards and country-of-origin. Corp. Commun. Int. J. 2016, 21, 230-245. [CrossRef]

33. Moll, J.; Burns, J.; Major, M. Institutional Theory. In Methodological Issues in Accounting Research; Hoque, Z., Ed.; Spiramus: London, UK, 2006.

34. Shepard, J.; Betz, M.; O'Connell, L. The Proactive Corporation: Its Nature and Causes. J. Bus. Ethics 1997, 16, 1001-1010. [CrossRef]

35. Ali, W.; Frynas, J.G.; Mahmood, Z. Determinants of Corporate Social Responsibility (CSR) Disclosure in Developed and Developing Countries: A Literature Review. Corp. Soc. Responsib. Environ. Manag. 2017, 24, 273-294. [CrossRef]

36. Campbell, J.L. Why would corporations behave in socially responsible ways? An institutional theory of corporate social responsibility. Acad. Manag. Rev. 2007, 32, 946-967. [CrossRef]

37. El Ghoul, S.; Guedhami, O.; Kim, Y. Country-level institutions, firm value, and the role of corporate social responsibility initiatives. J. Int. Bus. Stud. 2017, 48, 360-385. [CrossRef]

38. Dhaliwal, D.S.; Radhakrishnan, S.; Tsang, A.; Yang, Y.G. Nonfinancial disclosure and analyst forecast accuracy: International evidence on corporate social responsibility disclosure. Account. Rev. 2012, 87, 723-759. [CrossRef] 
39. Ioannou, I.; Serafeim, G. What drives corporate social performance? The role of nation-level institutions. J. Int. Bus. Stud. 2012, 43, 834-864. [CrossRef]

40. Cahan, S.F.; de Villiers, C.; Jeter, D.C.; Naiker, V.; van Staden, C.J. Are CSR disclosures value relevant? Cross-country evidence. Eur. Account. Rev. 2016, 25, 579-611. [CrossRef]

41. García-Sánchez, I.M.; Cuadrado-Ballesteros, B.; Frias-Aceituno, J.V. Impact of the Institutional Macro Context on the Voluntary Disclosure of CSR Information. Long Range Plan. 2016, 49, 15-35. [CrossRef]

42. Carroll, A.B. A History of Corporate Social Responsibility: Concepts and Practices. In The Oxford Handbook of Corporate Social Responsibility; Crane, A., McWilliams, A., Matten, D., Moon, J., Siegel, D., Eds.; Oxford University Press: Oxford, UK, 2008; pp. 19-46.

43. Blasco, M.; Zolner, M. Corporate Social Responsibility in Mexico and France: Exploring the Role of Normative Institutions. Bus. Soc. 2010, 49, 216-251. [CrossRef]

44. Jennings, P.D.; Hoffman, A.J. Institutional Theory and the Natural Environment: Building Research through Tensions and Paradoxes; Sage Publications: London, UK, 2017; pp. 759-785.

45. Khanna, T.; Palepu, K.; Srinivasan, S. Disclosure Practices of Foreign Companies Interacting with U.S. Markets. J. Account. Res. 2004, 42, 475-508. [CrossRef]

46. Xiao, J.Z.; Gao, S.S.; Heravi, S.; Cheung, Y.C.Q. The impact of social and economic development on corporate social and environmental disclosure in Hong Kong and the UK. Adv. Int. Account. 2005, 18, 219-243. [CrossRef]

47. Buhr, N.; Friedman, M. Culture, Institutional Factors and Differences in Environmental Disclosure between Canada and The United States. Crit. Perspect. Account. 2001, 12, 293-322. [CrossRef]

48. Thorne, L.; Mahoney, L.S.; Manetti, G. Motivations for issuing standalone CSR reports: A survey of Canadian firms. Account. Audit. Accountab. J. 2014, 27, 686-714. [CrossRef]

49. Shi, Y.; Magnan, M.; Kim, J. Do countries matter for voluntary disclosure? Evidence from cross-listed firms in the US. J. Int. Bus. Stud. 2012, 43, 143-165. [CrossRef]

50. Goodrich, P.S. Cross-national financial accounting linkages: An empirical political analysis. Br. Account. Rev. 1986, 18, 42-60.

51. Adams, C.; Harte, G. The Changing Portrayal of the Employment of Women in British Banks' \& Retail Companies' Corporate Annual Reports. Account. Organ. Soc. 1998, 23, 781-812.

52. Williams, S.M. Voluntary environmental and social accounting disclosure practices in the Asia-Pacific region: An international empirical test of political economy theory. Int. J. Account. 1999, 34, 209-238. [CrossRef]

53. Adams, C. Internal organisational factors influencing corporate social \& ethical reporting: Beyond current theorising. Account. Audit. Accountab. J. 2002, 15, 223-250.

54. Orij, R. Corporate Social Disclosures in the Context of National Cultures \& Stakeholder Theory. Account. Audit. Accountab. J. 2010, 23, 868-889.

55. Robbins, L. On the Relations between Politics and Economics. In Politics and Economics; Palgrave Macmillan: London, UK, 1963.

56. The Legitimising Effect of Social \& Environmental Disclosures Deegan, C. The Legitimising Effect of Social \& Environmental Disclosures-A Theoretical Foundation. Account. Audit. Account. J. 2002, 15, $282-311$.

57. Bani-Khalid, T.; Kouhy, R. The Impact of National Contextual Factors on Corporate Social and Environmental Disclosure (CSED): The Perceptions of Jordanian Stakeholders. Int. Rev. Manag. Bus. Res. 2017, 6, 556.

58. Frynas, J.G.; Stephens, S. Political Corporate Social Responsibility: Reviewing Theories and Setting New Agendas. Int. J. Manag. Rev. 2015, 17, 483-509. [CrossRef]

59. Whitley, B.E. Right-wing Authoritarianism, Social Dominance Orientation, \& Prejudice. J. Personal. Soc. Psychol. 1999, 77, 126-134.

60. Scherer, A.G. Theory Assessment and Agenda Setting in Political CSR: A Critical Theory Perspective. Int. J. Manag. Rev. 2018, 20, 387-410. [CrossRef]

61. De Villiers, C.; Marques, A. Corporate social responsibility, country-level predispositions, and the consequences of choosing a level of disclosure. Account. Bus. Res. 2016, 46, 167-195. [CrossRef]

62. Di Tella, R.; Ades, A. Rents, Competition, and Corruption. Am. Econ. Rev. 1999, 89, 982-993.

63. Walters, K. Corporate Social Responsibility and Political Ideology. Calif. Manag. Rev. 1977, 19, 40-151. [CrossRef]

64. Hanlon, G.; Fleming, P. Updating the Critical Perspective on Corporate Social Responsibility. Sociol. Compass 2009, 3, 937-948. [CrossRef] 
65. Amor-Esteban, V.; García-Sánchez, I.M.; Galindo-Villardón, M.P. Analysing the Effect of Legal System on Corporate Social Responsibility (CSR) at the Country Level, from a Multivariate Perspective. Soc. Indic. Res. 2017, 1-18. [CrossRef]

66. La Porta, R.; Lopez-de-Silanes, F.; Shleifer, A.; Vishny, R.W. Legal determinants of external finance. J. Financ. 1997, 52, 1131-1150. [CrossRef]

67. Doupnik, T.S.; Salter, S.B. External Environment and Accounting Practice: A Preliminary Test of a General Model of International Accounting Development. Int. J. Account. Educ. Res. 1995, 30, 189-207.

68. Ball, R.; Kothari, S.P.; Robin, A. The effect of international institutional factors on properties of accounting earnings. J. Account. Econ. 2000, 29, 1-51. [CrossRef]

69. Kolk, A.; Perego, P. Determinants of the adoption of sustainability assurance statements: An international investigation. Bus. Strategy Environ. 2010, 19, 182-198. [CrossRef]

70. De Villiers, C. Why do South African companies not report more environmental information when managers are so positive about this kind of reporting? Medit. Account. Res. 2003, 11, 11-23. [CrossRef]

71. Momin, M.A.; Parker, L.D. Motivations for corporate social responsibility reporting by MNC subsidiaries in an emerging country: The case of Bangladesh. Br. Account. Rev. 2013, 45, 215-228. [CrossRef]

72. Simnett, R.; Vanstraelen, A.; Chua, W.F. Assurance on Sustainability Reports: An International Comparison. Account. Rev. 2009, 84, 937-967. [CrossRef]

73. Hamamura, T. Are Cultures Becoming Individualistic? A Cross-Temporal Comparison of IndividualismCollectivism in the United States and Japan. Personal. Soc. Psychol. Rev. 2012, 16, 3-24. [CrossRef] [PubMed]

74. Hofstede, G.H. The Cultural Relativity of Organizational Practices and Theories. J. Int. Bus. Stud. 1983, 82, 76-88. [CrossRef]

75. Barako, D.G.; Brown, A.M. Corporate social reporting and board representation: Evidence from the Kenyan banking sector. J. Manag. Gov. 2008, 12, 309-324. [CrossRef]

76. Ntim, C.G.; Soobaroyen, T.; Broad, M.J. Governance structures, voluntary disclosures and public accountability. The case of UK higher education institutions. Account. Audit. Account. J. 2017, 30, 65-118. [CrossRef]

77. Ntim, C.G.; Soobaroyen, T. Black Economic Empowerment Disclosures by South African Listed Corporations: The Influence of Ownership and Board Characteristics. J. Bus. Ethics 2013, 116, 121-138. [CrossRef]

78. Al-Bassam, W.M.; Ntim, C.G.; Opong, K.K.; Downs, Y. Corporate Boards and Ownership Structure as Antecedents of Corporate Governance Disclosure in Saudi Arabian Publicly Listed Corporations. Bus. Soc. 2018, 57, 335-377. [CrossRef]

79. Tagesson, T.; Blank, V.; Broberg, P.; Collin, S.O. What explains the extent and content of social and environmental disclosures on corporate websites: A study of social and environmental reporting in Swedish listed corporation. Corp. Soc. Responsib. Environ. Manag. 2009, 16, 352-364. [CrossRef]

80. Doh, J.; Guay, T. Corporate social responsibility, public policy, and NGO activism in Europe and the United States: An institutional stakeholder perspective. J. Manag. Stud. 2006, 43, 47-73. [CrossRef]

81. Macaulay, S. Non-contractual relations in business: A preliminary study. Am. Sociol. Rev. 1963, $28,55-67$. [CrossRef]

82. Williamson, O.E. The Economic Institutions of Capitalism; Free Press: New York, NY, USA, 1985.

83. Gray, S.J. Towards a theory of cultural influence on the development of accounting systems internationally. Abacus 1988, 24, 1-15. [CrossRef]

84. Adhikari, A.; Tondkar, R.H. Environmental factors influencing accounting disclosure requirements of global stock exchanges. J. Int. Financ. Manag. Account. 1992, 4, 75-105. [CrossRef]

85. Gray, S.J.; Campbell, L.G.; Shaw, J.C. International Financial Reporting: A Comparative International Survey of Accounting Requirements and Practices in 30 Countries; MacMillian: London, UK, 1984.

86. Marano, V.; Kostova, T. Unpacking the Institutional Complexity in Adoption of CSR Practices in Multinational Enterprises. J. Manag. Stud. 2016, 53, 28-54. [CrossRef]

87. Cormier, S.; Magnan, M.; Van Velthoven, B. Environmental disclosure quality in large German companies: Economic incentives, public pressures or institutional conditions? Eur. Account. Rev. 2005, 14, 3-39. [CrossRef]

88. Déjean, F.; Martinez, I. Environmental disclosure and the cost of equity: The French case. Account. Eur. 2009, 6, 57-80. [CrossRef] 
89. Malone, D.; Fries, C.; Jones, T. An empirical investigation of the extent of corporate financial disclosure in the oil and gas industry. J. Account. Audit. Financ. 1993, 8, 249-279. [CrossRef]

90. Najah, A.; El Ghoul, S.; Guedhami, O.; Suh, J. Corporate Social Responsibility and Credit Ratings. J. Bus. Ethics 2013, 117, 679-694.

91. Cheng, B.; Ioannou, I.; Serafeim, G. Corporate Social Responsibility and Access to Finance. Strateg. Manag. J. 2014, 35, 1-23. [CrossRef]

92. Cornell, B.; Shapiro, A.C. Corporate stakeholders and corporate finance. Financ. Manag. 1987, 16, 5-14. [CrossRef]

93. Adams, C.; Hill, W.Y.; Roberts, C. Corporate social reporting practices in Western Europe: Legitimating corporate behavior? Br. Account. Rev. 1998, 30, 1-21. [CrossRef]

94. D'Amico, E.; Coluccia, D.; Fontana, S.; Solimene, S. Factors influencing corporate environmental disclosure. Bus. Strategy Environ. 2016, 25, 178-192. [CrossRef]

95. García-Sánchez, I.M. Corporate social reporting: Segmentation and characterization of Spanish companies. Corp. Soc. Responsib. Environ. Manag. 2008, 15, 187-198. [CrossRef]

96. Stanny, E.; Ely, K. Corporate environmental disclosures about the effects of climate change. Corp. Soc. Responsib. Environ. Manag. 2008, 15, 338-348. [CrossRef]

97. Guthrie, J.; Parker, L. Corporate social disclosure practice: A comparative international analysis. Adv. Public Interest Account. 1990, 3, 159-176.

98. Bansal, P.; Clelland, I. Talking trash: Legitimacy, impression management, and unsystematic risk in the context of the natural environment. Acad. Manag. J. 2004, 47, 93-103.

99. Benlemlih, M.; Girerd-Potin, I. Corporate social responsibility and firm financial risk reduction: On the moderating role of the legal environment. J. Bus. Financ. Account. 2017, 44, 1137-1166. [CrossRef]

100. Chang, T.C.; Yan, Y.C.; Chou, L.C. Is default probability associated with corporate social responsibility? Asia-Pac. J. Account. Econ. 2013, 20, 457-472. [CrossRef]

101. Hussain, W.; Moriarty, J. Accountable to Whom? Rethinking the Role of Corporations in Political CSR. J. Bus. Ethics 2018, 149, 519-534. [CrossRef]

102. Baldini, M.; Dal Maso, L.; Liberatore, G.; Mazzi, F.; Terzani, S. Role of country-and firm-level determinants in environmental, social, and governance disclosure. J. Bus. Ethics 2018, 150, 79-98. [CrossRef]

103. Doidge, C.; Karolyi, G.A.; Stulz, R.M. Why do countries matter so much for corporate governance? J. Financ. Econ. 2007, 86, 1-39. [CrossRef] 